\title{
A Military Zone in a Dwelling of the Buddhas: Appropriation and Re-appropriation of the Cultural Landscape in Transbaikalia
}

\author{
Ayur Zhanaev
}

DOI: 10.21104/CL.2020.3.02

\begin{abstract}
This article considers a place as being filled with the symbolic meanings of the different groups controlling that place in different periods of history. It focuses on the example of the Soviet military zone in Transbaikalia, which was created on the site of the Buryat Buddhist monastery of Tsugol in the early 1930s. The military zone went on to replace the previous identity of the place by appropriating the meanings and symbols attached to the monastery. Fifty years later, in the post-Soviet period, the place was "reappropriated" by the Buryat Buddhist monastery. The article discusses the practices of appropriation and re-appropriation of the place, and the way the competing narratives merge into a multilocal phenomenon.
\end{abstract}

\section{Key words}

cultural landscape, place, social change, post-Soviet military base, Soviet modernity, Buryat Buddhism, borderland

\section{Acknowledgment}

I would like to thank the first editors, namely Dominika Czarnecka, Dagnosław Demski and Jan Pohunek who organized the Second Seminar on Post-Cold War Military Zones in Central and Eastern Europe (Prague, November 6-8th 2018), to which the manuscript was initially prepared. I would also like to express my gratitude to Michał Głuszek and Michael Gulyaév for reading and commenting the first draft of this article.

\section{Contact}

Ayur Zhanaev, PhD, assistant professor in the Institute of Social Prevention and Resocialization, Department of Applied Social Sciences and Resocialization, University of Warsaw, Podchorążych 20, 00-721 Warsaw, Poland; e-mail: a.zhanaev@uw.edu.pl.

\section{Jak citovat / How to cite}

Zhanaev, Ayur. (2020). A Military Zone in a Dwelling of the Buddhas: Appropriation and Re-appropriation of the Cultural Landscape in Transbaikalia. Český lid 107, 309-334. doi:http://dx.doi.org/10.21104/ CL.2020.3.02 
The Buddhist monastery of Tsugol was founded at the beginning of the 19th century on the steppes of eastern Transbaikalia. ${ }^{1}$ The proximity of the Russian-Chinese border made it possible for local Buryat lamas to maintain close contacts with the Buddhist world and their kin in the Qing Empire and allowed them to develop this area into one of the largest centers of Buryat Buddhism. However, during the Soviet period being so close to the border constituted a disadvantage for the monastery. The region was heavily militarized due to potential threats from the pro-Japanese Manchukuo state in the 1930s and from China in the 1960s following the Sino-Soviet split.

Despite the militarization and the devastating anti-religious campaign in the region, the temple complex was preserved and in the post-Soviet period has come to the attention of Buryats as one of the few cultural sites that survived the Soviet era. During my fieldwork in the region, I frequently heard locals asking how it was that the temple, unlike other Buryat monastic compounds, had been preserved. The explanations of this extraordinary fact are tales of luck and miracle. The questions people pose and the histories they construct uncover the ways they think of a "place" and its identity.

When referring to "place" I do not imply any objective point or entity, but accept Edward Casey's view of place as an 'event' or a process. It is constantly being made and remade in accordance with a particular dynamism (Casey 1996). Place is transformed by stories attached to objects and, in this way, is closely connected with the community related to the place. In its recent history, Tsugol has been inhabited by different communities and each of them has created stories and then constructed the place and its past in accordance with their cultural background. Thus, the main goal of this article is to present these practices of appropriation and re-appropriation of the place, and the way the competing narratives form a multilayered cultural landscape.

I apply the term "appropriation" as it is used in Polish sociology to describe the way the territories allotted to Poland after the Second World War (i.e. former German settlements or the Eastern Carpathians region) were symbolically included into the Polish collective representations (Demski - Czarnecka 2015; Wierzejska - Shumylovych 2018). In this kind of area, I think the idea of "appropriation" can be very helpful in describing the process of the military zone taking over the monastery in Transbaikalia (see Figure 1). I also introduce the term "re-appropriation" to describe the process of the monastery returning to life after the military

1 The term Transbaikalia is meant to refer to the historical territories located east of the Baikal. I also mention in the text Trans-Baikal Territory, which denotes Zabaikal'ski krai - a federal subject of the Russian Federation. 
zone was abandoned. Although there were attempts to clean the place of Buryat cultural and religious meanings (appropriation) during the period of the military zone, contemporary Buryat representations of the place have ignored the Soviet military period and have made direct reference to the pre-1933 Buryat religious and cultural history of the place (re-appropriation). The article will also introduce some elements of the Buryat view of the place and the objects it holds, which may have important theoretical value. The case of Tsugol vividly shows the multiple narratives that were competing over the identity of the place and now form a multilayered cultural landscape. In this context, all the collected narratives could be associated with Margaret Rodman's idea of multilocality, which implies polysemic meanings of place for different users and that a single place may be experienced quite differently (Rodman 1992: 647).

\section{Methodology of data collection}

My personal experience related to the monastery is important for this article from the methodological point of view. In 2008, while studying at Buryat State University, I participated in a project focusing on the translation of a book from Buryat into English entitled The Buddhist Monastery of Souge ${ }^{2}$ by Dambinima Tsyrendashiev, a local historian. It was a challenging task for a team of seven students headed by Professor Polina Dashinimaeva. The original 365-page Buryat-language book was published in 2008 and covered the history of the Tsugol monastery in the 18th and 19th centuries. Tsyrendashiev planned to write a second volume of the book dedicated to the history of the monastery in the 20th century. In 2010, I was asked by Professor Dashinimaeva to help Tsyrendashiev to complete the second volume of his book. I was involved in digitalizing and sorting out his archives, which contained documents, testimonies, interviews and oral histories related to the monastery. Unfortunately, Tsyrendashiev was not able to finish his work due to illness. The second volume entitled Semü̈̈n Sag [Troublesome Times] was completed in 2012 after his death by the author's daughter, Tsytsygma. However, for many reasons, some of the collected stories about the monastery were not included and I would like to cite some of them in my article.

In August 2012, I went to Tsugol for the first time with a team of Polish anthropologists headed by Professor Ewa Nowicka-Rusek. ${ }^{3}$ By then I had

2 Sougel, Suugel, Tsugol and Tsuugel are different spellings of the same name.

3 As a part of the project "Between Russia, Mongolia and China. Buryats and the 21st century challenges" financed by the National Science Centre (NCN), decision number DEC-2011/03/B/HS6/01671. 
quite a good knowledge of the history of the place and remembered the stories and legends related to the area from my work with Tsyrendashiev. Thus, the analysis presented in this article is a result of my own research, which included work with the author Tsyrendashiev in the period 20082010, and my own fieldwork in Tsugol in 2012.

Many anthropologists warn about the risk of attributing various centric perspectives while theorizing on place: cultural practices and social institutions "pervade every level of perceptions" (Casey 1996: 18-19). A researcher's assumption concerning a place and its characteristics might significantly differ from the assumptions of the local community the researcher is studying (Clifford 2000; Smyrski 2018). Specifically, most of the narratives collected here are those of local Buryats and also Russians. It is very hard in the local Transbaikalian context to categorize those narratives according to "ethnicity". There are no narratives from former Soviet servicemen who served there, most of whom left Tsugol in the late 1980 s. However, on the Internet I managed to find social network groups of former servicemen who publicly share their memories of Tsugol and upload their photos from those times. Such social media groups could serve as empirical material for qualitative research (Dondukov 2019: 15). However, due to privacy issues, I will not be able to provide direct links to these citations. Nevertheless, they are interesting for me as a changing manifestation of local memory ${ }^{4}$ and an attitude towards events, places and objects. Cultural landscape is not something constant and unchangeable, and is filled with ambiguity, transition, and hybridity (Demski - Czarnecka 2015: 98), which can clearly be seen in the case of Tsugol.

\section{Buddhist monasteries during Soviet times}

Before the 1917 Bolshevik revolution, there were 36 Buddhist monasteries, called datsans, and over hundred minor shrines in Transbaikalia. Datsans played an important role as educational and cultural centers for the Buryat population. In early Soviet times, between 1917 and the early 1930s, Buddhism experienced relative freedom. Surprisingly, during this period, about 10 new monasteries were established in the region. Everything changed in the 1930s when the Soviet authorities had grown much stronger and began a harsh anti-religious campaign aimed at rooting out Buddhism along with other religions throughout the USSR. This campaign resulted in the almost complete destruction of Buddhist monasteries and shrines, and purges of lamas (Sinitsyn 2013: 484). Many monastery

\footnotetext{
4 By the term memory, in accordance with Barbara Szacka, I mean the various narratives people assert regarding their past (Szacka 2006: 37).
} 
buildings were taken apart and transported to newly created collective farms to be used as public premises, such as schools, community administration buildings and village halls. Their rich interiors, sculptures, paintings and libraries were pillaged. Only a few artefacts survived, which were held in museums, archives, and private collections or hidden by local people. In addition to the utter destruction, the Soviet authorities used symbolic contamination as a method of downgrading these places of worship. For example, the Anaa datsan in the Khori aimag (district) served as a slaughterhouse before it was completely demolished; the Tamcha datsan in Selenginski aimag was used as a transit prison; and the Aga datsan in Aga Okrug served as a tuberculosis sanatorium. The Buryat Buddhists often saw these actions as buzar, a kind of symbolic, ritual or even spiritual contamination of the aryuun, aglag, a "pure" place. In the late 1930s, there were attempts by some local officials and scholars to save some of the temples in the Yangaazhin, Tsugol, and Tamchiin datsans in the form of ethnographic museums, but these attempts failed as the anti-religious campaign in Russia accelerated (Sinitsyn 2013: 153; Andreev [in] Sinitsyn 2013: 463-464). By the time the Soviet Union collapsed in 1991 only a few of the original Buddhist temples survived, including two temples of the Tamcha datsans, and a few temples of the Aga and the Tsugol datsan. This article focuses on the history of the Tsugol datsan, which was part of a major military base during Soviet times.

\section{Tsugol datsan: the possibilities and threats of the borderland}

The history of the Tsugol datsan, which also carries the Tibetan name Dashi Choinpeling (the Land of Multiplication of Happiness Teaching), begins in 1801 when a felt yurt mobile shrine was created to serve the local population that was unable to travel to other distant datsans. Later, in 1827, the first stationary temple was built in Tsugol. The place chosen for the future Buddhist shrine was not accidental. According to Buddhist geomancy, it was considered acceptable if a monastery were built on the southern flank of a mountain and on the northern bank of a river. Different Buryat communities were looking to host the monastery, but the abbot Lama Dandarai preferred the location close to the Russian-Chinese border. According to Tsyrendashiev, Lama Dandarai said that "If the datsan is located near the border, it will serve as an unofficial transit point for scholars and siddhis [people of spiritual power and advancement A. Zh.] from the south" (Tsyrendashiev 2008: 36).

Thus, the location of the Tsugol monastery was determined by its vicinity to the border, which allowed for closer contacts with the Qing Empire, 
primarily Barga, Inner and Outer Mongolia, where the Geluk-pa school of Buddhism was officially protected. The Tsugol lamas even traveled to Tibet to get the final approval for the monastery location from the Dalai Lama (Tsyrendashiev 2008: 36). According to a local legend, there were other signs that pointed to the future location of the dastan. The mountain Bulgata, north of the future monastery, was a place where the goddess Balden Lhamo once appeared to predict the future location of the datsan. The donkey she was riding left its hoof prints on a black stone on the bank of Onon River, which was a sacred object for many generations of Buryats.

By 1900 the Tsugol monastery had grown into an influential Buddhist center in Transbaikalia offering Buryats classic Buddhist education. The monastery offered studies in Buddhist philosophy, medicine, astrology and the arts. Besides the main temple, which was built with elements of Chinese and Tibetan styles (Zhamsueva - Luvsan 2018) (see Figure 2), the Tsugol datsan had twenty other buildings, including a hospital, a printing house, large prayer wheels khürde and multiple stupas suburgans. Tsugol datsan's printing house published the full range of canonical Buddhist literature and sent books to other regions of ethnic Buryatia ${ }^{5}$ (Vanchikova - Gomboeva 2010). A town housing 1,500 lamas and a lay population had grown up near the monastery.

Places possess the power of gathering and holding community memories (Casey 1996) and Tsugol is no exception. Tsyrendshiev describes the place in the first chapter of his book as follows: "The place called Sougel is located on the wide headstream of the Queen Mother river Onon - the cradle native land of Genghis Khan. [...] If one looks around in all four directions from the upland, one can see the widespread Khünkher steppe stretching far into the haze. The renowned Pine Tree-Army lines up pronouncedly in array at the southern ridge of the steppe area that holds the legend of the hero Babzha-Baatar, and the whole steppe is soaked with sorrowful songs of Princess Balzhan" (Tsyrendashiev 2008: 18). The elements of the surrounding landscape of Tsugol are imbued with the stories and associations familiar to Buryats in every part of ethnic Buryatia. The "renowned" places and historical and legendary figures associated with this place have an important role in the Buryat and, more generally, Mongol history.

5 The term "ethnic Buryatia" is currently used by Buryats and in academia to emphasize the fact that the Buryat people live not only in the Republic of Buryatia, but also in the neighboring Irkutsk Region (oblast') and the TransBaikal territory. 
The vicinity to the border that determined the initial location of the monastery might have been a bad omen for the datsan. The occupation of northern China by Japan in the early 1930s led to confrontations with the Soviet Union. In 1932, a Soviet military unit was deployed in Tsugol and the Red Army turned the monastery into military garrison. The monastery was officially closed in 1933 and was probably one the first Buryat datsans to be closed.

The whole village was inhabited by lamas, more than 1,000 lamas were living here. There wasn't just this one temple [main temple - A. Zh.] here. There were many [temples $-A$. Zh.]. The temples were blown up and the lamas purged. The majority of lamas, around a thousand, were sent to do forced-labor logging in Krasnoyarsk region, only a few ever returned (DS750613, Buryat man, local lama, 40 years old, Tsugol, 2012)

Around 300 lamas were reportedly taken out of the monastery and murdered. According the Russian Buddhist Sangha, around 130 lamas from Tsugol escaped to Barga and Inner Mongolia ${ }^{6}$ along with thousands of lay people, while most of the lamas were sent to labor camps. Only a few of the younger disciples survived, returning to their families disrobed.

In 1935, on the basis of Decree No. 28 of the Soviet Central Executive Committee, the religious objects and attributes of Buddhist practice belonging to the Tsugol datsan were transferred "by way of a grant" to representatives of the Anti-religious Museum of Buryat-Mongolian Autonomous Soviet Socialist Republic (BMASSR). Some artefacts including an 8.5-meter statue of Buddha Maidari was later transferred to the Museum of the History of Religion and Atheism in what was then Leningrad. On the basis of the Decree of the Central Executive Committee of the BMASSR dated August 8, 1936, the buildings of the Tsugol datsan were passed "by way of a grant" to the 57th Rifle division of the People's Commissariat for the Defense of the Soviet Union (Zhamsueva - Luvsan 2018).

\section{Appropriation of the borderland}

During the First World War and then the Bolshevik revolution, 32.5\% of Aga Buryats migrated to Mongolia (Boronoeva 2006: 38; after: Szmyt 2013: 152), and following the collectivization campaign and purges of the

6 https://sangharussia.ru/datsans/tsugolskij-datsan-dashi-chojpelling, accessed on July $5,2020$. 
1930s even more Buryats crossed the state border and settled in China and Mongolia. ${ }^{7}$ Because all Buryats had relatives across the border, many were considered suspicious elements by the Soviet authorities. Due to the potentially disloyal mobility of the nomads and the generally tense situation along the border in the 1930s, the local Buryat population was transferred to other areas of the region. The memories of those times are still alive among the local population:

In the past, the Buryat population near the border was very dense. During Stalin's time the majority of the local population was exiled to the Krasnoyarsk region to do forced-labor logging, to the Kamchatka peninsula, and to the area of the White Sea-Baltic Canal construction site and other places. The majority was sent to Krasnoyarsk and only a few came back alive. That's why Borzinski, Zabaikalski, Ononski, part of Olozyaninski and Priargunski districts - these districts near the border with Mongolia ... the majority of the contemporary population ... is Russian ... and the Buryats were expelled from there. (DS750613, Buryat man, 40 years old, Tsugol, 2012)

The mobility of nomadic Buryats was limited, and, with the advancing sedentarization in the collective farms, the whole geography of the region was significantly changing. ${ }^{8}$ Ivan Peshkov writes that "the specificity of Eastern Trans-Baikalia lies in the semi-military form of its border urbanization and the almost total, tense ideological control over the cultural sphere of activities. This caused the long-standing practice of dematerialization of counter-memory through sterilization of the region against any physical signs of its unofficial past" (Peshkov 2014: 97). The regions of eastern Transbaikalia beyond the Aga Buryat autonomy is also perceived by the local Buryats as a place of cultural and linguistic "dematerialization":

7 The Buryat population of the Russian Empire, which was 288,883 according to a 1897 census, decreased to 237,000 in 1926, and to 225,000 in 1939 (Nimaev, 1993: 45-46). For more information about Buryats in China and Mongolia see (Namsaraeva 2012; Szmyt 2013)

8 In 1923, the Buryat-Mongolian Autonomous Soviet Socialist Republic was established. In 1937, the territory of the Republic was significantly reduced: Ust'-Orda Buryat national area (okrug) and Aga Buryat national area were detached from the Republic and were merged with the Irkutsk and Chita regions (oblast'). The territories of the Aga Buryat area, located close to the state border, were removed from the autonomy. Rumors spread among the locals that the Tsugol area would be excluded from the Buryat autonomy as well. 
... the Buryats on the side of the Trans-Baikal Territory (Zabaikalski krai), closer to the border with China, have practically lost their language. They were Russified, just like that... They're not observing traditions... If some senior person comes up and speaks to them in the Buryat language, they will not understand. (DS750616, Buryat man, 20 years old, Tsugol, 2012)

The same happened in Tsugol where only a few Buryat families were allowed to stay and who are said to be linguistically and culturally assimilated. When, in the post-Stalin period, some lamas returned from the camps, they were not allowed to go back to Tsugol and were banned from visiting the place in the future. The Soviet authorities were afraid of lamas reviving the Buddhist traditions and forced them to settle away from their former monasteries:

Even those who came back [from the labor camps - A. Zh.] were not allowed to live here where their homes used to be. They had to settle in the neighboring districts and could not come back until 1990s when the Soviet Union collapsed. There was this Zhimba lama, an old lama who survived the purges, who was not allowed to come back to his place [Tsugol - A. Zh.] and thus settled in Darasun. Although it is a district nearby, he longed to live where his home was, but could not come here until the 1990s ... (DS750613, Buryat man, 40 years old, Tsugol, 2012)

The concept of the state border as a line of sovereignty and the protection of it carried a special cultural and ideological value in the Soviet state (Humphrey 2014; 2015), which was rapidly transforming the cultural landscape of the region. Born in the Aga district in 1920 Tsyrendashiev witnessed the changing Buryat reality. He lived through mass collectivization, the anti-religious movement, and the purges. In the more "liberal" 1960 s, he worked as an official responsible for preservation of historical monuments and attempted to include the monastery in the state list of local cultural heritage:

In 1967, I visited the Sougel datsan for the first time and found it so beautiful. I spoke about it to the executive committee of the district. However, one local boss responded in a mix of Buryat and Russian words: "Don't say that this landmark was built by Aga Buryats. The temple was built thanks to the Russians and the Chinese". I grew angry and started arguing with him. The boss then said "Boy, don't get so excited if you don't have any evidence or facts. The temple was 
built by somebody else, but not by Buryats." At that time, I had no facts to support my arguments. That incident made me interested in the history of the Sougel datsan (Tsyrendashiev 2008: 13).

The words of the local boss carried the evolutionist assumptions of the general Soviet attitude toward ethnic minorities, which considered the culture of the nomadic Buryat population backward and in need of elevation to the more advanced level of modern Soviet culture. The Soviet policy of modernization aimed at "upgrading" the local population was met with an ambivalent reaction from the local Buryat population. Tsyrendashiev in his book laments this: "When this land was taken over by the military, the road from the Suugel datsan to Nurinsk was paved. During the construction of the road, a holy rock was blown to pieces. The Burkhans (Deity) depictions on the cliffs disappeared along with the stone with the donkey's hoof imprints. The stone was pushed down into Onon River and it is impossible to recover it. The northern steppe of Tsugol became the garrison's waste disposal site. So Lhama Hill was desecrated" (Tsyrendashiev 2008: 20). Over the years the Tsugol area, which was an important center of Buryat culture, was gradually transformed into a closed military zone devoid of the Buryat component ${ }^{9}$.

\section{Rise and fall of the military zone}

Since the 1930s, the border with China has been a tense one. In the late 1930s, the Soviet Union was in confrontation with Japan, which controlled northern China. In the 1960s, there were several military clashes with Communist China in the area. For many years the local population lived with the threat of war and, with China in the period 1960-1980s, there was a possibility of nuclear war (Gerson 2010). The military presence was expanding from the 1930s, when the first Red Army servicemen appeared in the Tsugol area. In 1933, a boarding school named "15 years of the Red Army" was built in Tsugol for children from the surrounding villages. The military population grew considerably after 1946, when

9 In 1982, parts of the Soviet film The Order: to Cross the Border by Yuri Ivanchuk was shot in what was formerly the Tsugol datsan. The main Tsugol temple, which featured throughout the film, was portrayed as a monastery in Manchuria. The film showed the monastery collaborating with the Japanese military, who were fighting against the Red Army. After watching the film, many Buryats were disappointed that the Buryat datsan had been presented in the film as a foreign and hostile place. One fragment of the original wall around the main temple was blown up during filming of a battle scene with a tank. 
large numbers of Red Army officers arrived from other parts of the Soviet Union, mainly Russia, Ukraine and Belarus. Many of the newcomers were put up in the houses of the purged lamas, while the former monastery buildings were transformed into barracks for soldiers and warehouses. The main temple was turned into military building and, according to a local lama, was used as a hospital during the Second World War (see Figure 3). After the war, the main temple was reportedly turned into a store for fuel and lubricant materials and possibly weapons. Military equipment was stored in the Choira temple (the temple of philosophical disputes).

The datsan was under the Ministry of Defense of the USSR until 1990 ... The temples were used as warehouses. For example, the mamba dugan [temple of medicine $-A$. Zh], the one surviving, green-colored building, was used to store medications. The buildings were guarded. (DS750616, Buryat man, 20 years old, Tsugol, 2012)

The area was very urbanized compared to the nearby local villages. Many buildings of utilitarian character embodying the idea of Soviet modernity were erected, including a massive military barracks, a hospital, a public canteen, a bakery, and garages. Gradually, more civilian and military buildings appeared in the area. According to the locals, a 3-storey building was built in the 1930s for high-ranking officers and several 5-storey blocks of flats were built in the 1970s for the families of the servicemen.

It was a very large military garrison, a major one. I think it was a military division. There was a general's house, there were barracks, and there were many buildings. There was a chemical defense battalion, and an armored vehicles unit. There were lots of military here. The town was very developed. (DS750616, Buryat man, 20 years old, Tsugol, 2012)

The landscape of Tsugol changed significantly over the years. The new inhabitants introduced new meanings to the place by renaming the streets, building new structures and moving the center away from the monastery. The main shrine, which was turned into a warehouse, lost its central place to Tsentralnaya (Central) street with its monument dedicated to the Soviet Union's victory over Nazi Germany (which the locals call pamyatnik [the monument]; see Figure 4). Military parades and officially approved May Day and Revolution Day rallies and other public gatherings were held here. The borderland is a zone of active manifestation of state affirmation - the narratives conceptualizing, legitimizing and appropriating the space are especially intensive in the border regions (Peshkov 2011: 110). 
The military community and the state authorities in Tsugol were legitimizing particular political and social orders.

With its newly acquired identity, the toponymy of Tsugol was also transformed. Many street names were changed. For example, the streets Sovietskaya (Soviet), Komsomolskaya (Communist Youth League), and Piervomaiskaya (May Day) appeared in Tsugol, reflecting the political and ideological changes in the country. The new non-Buryat inhabitants of Tsugol also gave their own unofficial names to the local places. The square in front of the gate to the main shrine was called Kozlinaya ploshchad (Square of the Goats), as goats reportedly liked roaming there. A major hill to the southwest of the town was now called by the Russian name Sopka Lyubvi ${ }^{10}$ (Love Hill). A hill northeast of the datsan was given the name Shkolnaya sopka (School Hill). A rivulet in Tsugol near the monastery acquired the folk name Pierieplyuika (Spit Over River). It is widely known that the procedure of changing official and folk place names is one of the main 'tools' for the appropriation of public space (Demski - Czarnecka 2015: 111).

Servicemen and their families were brought to Tsugol by the government from different parts of the Soviet Union and spent just a few years in Tsugol. The character of their relationship to the place, as suggested by Demski and Czarnecka, could be defined as "shallow" (Demski - Czarnecka 2015: 113). For the majority, it was a temporary place, unlike for the lamas before them, who came to the monastery as children and had been connected to the place throughout their lives. Eventually, in late 1980s, the servicemen were ordered to leave Tsugol.

In 2012, I went to Tsugol for the first time along with a team of Polish researchers and, for me as a Buryat, it was not a pleasant experience. The monastery is famous in Buryat public discourse as an important cultural site, but I discovered that it is presented in a deterritorialized and decontextualized manner. The images of a tranquil oriental shrine on the vast green steppe that I had seen beforehand on the Internet, on commemorative calendars and on postcards contrasted radically with the reality I saw. When approaching the area, one sees a row of urban blocks of flats which are completely out of place in the surrounding area (see Figure 5). Perhaps this semi-outsider's view is typical for many Buryats visiting the place.

10 This is a typical folk name for hills in many places in Russia. There are such hills in Chita, Ulan-Ude, Yakutsk, Ussuriysk, Petropavlovsk-Kamchatski and so on. In some cases, the name Sopka Lyubvi would replace or exist in parallel with the older name like Bayan-Togod [Wealthy Peacock] near Ulan-Ude and Nikolskaya sopka in Petropavlovsk-Kamchatski. 
The monastery, which now, once again, functions as a datsan with a number of lamas living there, had a wooden fence separating it from what remained of the military settlement next door. At that time, the military had left the town and had moved to a different location, albeit not very far from the area. Whole blocks of flats were left empty, many with broken windows and without water and electricity. In one of the buildings I saw a cow walking up the stairs. The local boarding school building collapsed and had to be moved into one of the former residential blocks of flats. It was a surreal picture not much different from the post-military "ghost towns" in Central and Eastern Europe (see Seljamaa - Czarnecka - Demski 2017). There were still some people living in the town, but mostly in small, shabby wooden huts. Members of the social group called "Tsugol" on Russian social media, when commenting on uploaded pictures of Tsugol, often expressed their disappointment with the contemporary state of the town: "These are the ruins of our childhood. Right there is Sopka Lyubvi, and at its foot people huddle forgotten by God and the government" (former inhabitant of Tsugol, citation from social media). As Ivan Peshkov correctly noticed, in eastern Transbaikalia "Soviet objects were moved from their former position as signs of modernity to the status of ruins, but this was accompanied by the simultaneous inability to return to old physical forms of representing the past or to invent new ones" (Peshkov 2014).

The people in Tsugol, unlike the residents of other villages in the Aga district, were suspicious of us strangers, two Polish researchers and myself, a Buryat, and were not very eager to speak to us. We only managed to speak to a few locals and some lamas in the monastery. They complained about the abject poverty, alcoholism and the high rates of crime in the town. The locals we spoke to had romanticized recollections of the period of the military zone as a time of order, development and prosperity. Tsugol in its military period was described as a place bustling with people and as an important outpost of the state, while now it was left depopulated and marginalized. This corresponds to the general phenomenon of Soviet nostalgia in the period of post-Soviet economic decline and deprivation. ${ }^{11}$

While walking around the settlement, I could see a lot of allusions and symbols that referred to the military past of the place. For example, there was a children's playground organized as a battlefield with tanks (see

11 The locals also speak of Tsugol as a sacred and clean place when it was a monastery: "Now the town has an unflattering image, but (before the establishment of the military zone) there were pine trees here, the place was ideally clean. The monastery disciples would keep the place clean, and there were a lot of them at that time". (DS750616, Russian woman, 50 years old, Tsugol, 2012) 
Figure 6), war paintings, and other military symbols. But these elements of identity seemed to be fading and becoming secondary to the association with the Buddhist shrine. The main temple greets visitors who approach the settlement with gleaming gold and other colors, in contrast to the grey surrounding scenery. It had regained its central position in the place, while the square with the Soviet-era monument was left empty and abandoned.

\section{How and why did the temple survive?}

The Soviet authorities finally declared the Tsugol monastery a cultural heritage object in $1980 .{ }^{12}$ By that time, the datsan buildings were already in poor condition due to lack of preservation and neglect. Soldiers had scribbled their names on the walls of the main shrine and some servicemen would take fragments of the decoration as souvenirs, but not all Soviet servicemen approved of such behavior:

For a long time, the datsan was in such a terrible state, and I know those who took fragments of it. I fortunately took nothing and I had no desire to do so, although I served for more than 10 years there, in 1972-1977 and in 1985-1991. ... I did not touch the temple, God sees it, neither did I do harm to the temple nor allow others to do it, although I saw some memorabilia collectors. As a rule, they were not good people. (Russian man, citation from social media)

Nevertheless, the major structures and decorations survived relatively intact. When I was conducting the research, I often encountered locals deliberating over why and how the temples had endured over time. In the locals' reflections there appear to be multiple layers of narratives that produce a multilocal cultural landscape. The dimensions of multilocality are predicated on the interacting presence of different voices in various geographical, cultural, and historical contexts (Rodman 1992). This kind of perspective perfectly fits the situation in Tsugol, where locals were trying to establish the reason for the datsan's survival. There two types of reasons that are accepted by the locals:

(1) In anthropological literature, place is often presented merely as a scene or an environment, because, as a rule, such descriptions render an outsider's optical perception (Smyrski 2018: 125-127). The practical

12 Number 751420167300006 in the Unified State Register of Cultural Heritage Objects (Historical and Cultural Monuments) of the Peoples of the Russian Federation; https://opendata.mkrf.ru/opendata/7705851331-egrkn, last accessed on May 15, 2019. 
and experiential aspects of place are often overlooked. In this connection, I would like to introduce the topic of non-human subjectivity, which is crucial for understanding the Buryat view of the place. The Buryats believe that the ability to react, resist and defend is inherent not only in human beings, but also in objects of everyday life. The monastery itself is considered to have such subjectivity and the survival of the Tsugol temples was considered the achievement of the place itself.

A Buddhist monastery has its guardian spirit known as sakhiusan. The Tsugol datsan has one named Choizhil. The Buryat interlocutors said Choizhil was a strong protector (shanga sakhiusantai) of the monastery: "The Dalai Lama has instructed that the monastery should have the Damdin-Choizhil protector and gave it the name Dashi-Choipolling. He said if you make the scuplture of Choizhil of iron, the monastery will have a long life" (Tsyrendashiev 2008: 36). The narratives of sakhiusans protecting monastery buildings are widespread in Buryatia. In the case of Anaa datsan in the Khorinski aimag of Buryatia, the Soviet authorities faced some difficulties while demolishing the main temple. An old woman told me what had happened: "They say that it was well protected by its sakhiusans. They tried to destroy it, with a bomb even, but they failed. This datsan was protected by such strong guardian deities" [DS750616, Buryat woman, 88 years old, Ułan Ude, 2012]. Although seriously damaged, the main structure still stands in Anaa datsan.

Another source of the subjectivity has its origins in the peculiar construction of the Tsugol temple. The stones and marble originally used came from the medieval Mongolian palace and town located nearby (Kradin - Baksheeva - Prokopets 2018: 71). Large stones that were placed in the foundations of the temple were brought from the ruins of the Mongolian town, along with some of the decoration. As Tsyrendashiev told me, the main goal was to bring the forces of the ancient Mongol imperial spirit to the new temple. The spiritual forces were to protect the temple, along with the low brick wall.

Tsyrendashiev also related a number of anecdotes that he heard himself when visiting the place. The locals believed that the temple had the spiritual powers to protect itself and take revenge for improper actions against it. He heard of a Soviet soldier who was ordered to remove some decorative elements called "mirrors" from a Buddhist temple. When he attempted to do so, he fell and seriously injured himself. Tsyrendashiev also heard of a senior officer's daughter asking her father to give her one of the golden sculptures of fallow deer from the roof of the temple. The sculptures were dismounted and given to the girl. Soon after, she broke her ribs while sledging in a ravine and was bed-ridden for a long period of time. Her father had to invite a healer shaman to bring her back to health. 
According to the local Buryats, there were a few accidents that made the military officers change their attitudes toward the temple. Over the years, the local Russian population grew to revere the monastery.

Some of the servicemen leaving this place, and there were a lot of them from different parts of the Soviet Union, tried to take away certain things from the temple as memorabilia. And we have a local legend or a myth ... when everything became open, there was a lot of iron roof material around. And one man took away some metal sheets from there and covered his cow shed with it, but soon he lost everything in a fire. After that nobody dares to touch the temple, nobody takes anything from there. (DS750616, Russian woman, 50 years old, Tsugol, 2012)

In this way, recent attention to non-human subjectivity perfectly fits into this cultural imaginary (Latour 1993). According to Bruno Latour, places and objects have the power of agency and can act upon reality. This is also a colloquial way of thinking about objects for the locals and thus an integral part of perceiving, and thus making the place.

(2) Many believe that, as the main landmark of the place, the temple survived thanks to the servicemen and thanks to the existence of the military zone in Tsugol. Reportedly, some Soviet Army officers took certain steps to save the temples:

There is a story. I don't remember the name of the officer. There was a case ... there was a decision made to blow up this datsan, the main temple, but an officer of high rank, a head of something, suggested they not destroy the building if it could be used as a store. Thanks to that officer the main temple has survived. (DS750613, Buryat man, 40 years old, Tsugol, 2012)

This is a more conventional reason for the temple's survival, i.e. the military preserved some buildings for utilitarian purposes, they were too big to be destroyed and could be put to some use. The fate of other datsans which were completely destroyed serve as proof. In an interview with a local TV channel, a Tsugol datsan lama said:

Shells on the second floor, weapons on the third. Our datsan was preserved because of the soldiers. In Soviet times, all the datsans were destroyed. In Russia, it turns out, only 3 of them have survived - the one in St. Petersburg, the Aga and Tsugol datsans."13

13 http://zab.tv/news/obshchestvo/stareyshiy-budda-zabaykalya-vossedaet-nakedrovom-trone-v-tsugole-/, last accessed on January 20, 2019. 
Some local people told me that the military zone which occupied the temple was the best thing that could have happened during the Soviet era. In the same manner, the so-called Soviet anti-religious museums preserved religious objects throughout the Soviet era. In the end, the military "prison" became a shelter for the temples. This kind of narrative strives to be the official narrative of the place as presented in a television broadcast by the Zvezda TV channel of the Russian Defense Ministry:

The day of the combat training coincided with khural - one of the most important Buddhist feasts. The worship ceremony gathers lamas and lay people from neighboring areas. They say that although their religion is the most peaceful, they will ask Buddha for good luck for the servicemen. After all, it was they who helped save one of the oldest monasteries of Transbaikalia in Tsugol. ${ }^{14}$

While an ambivalent attitude persists, the locals, including the Buryats, agree that the military zones are an inseparable and important part of the state. And this seems to be the point at which the two competing narratives of those who see the military zone as destructive and those who see it as a savior meet and agree. This is the point where mutual distrust loses its intensity, forming layers of cultural landscape. Nowadays, the Tsugol datsan is a shared landmark for the Russian and Buryat communities.

\section{Re-appropriation of the place}

In the 1990s, the Tsugol datsan experienced a revival, along with "traditional" Buryat culture. Because, unfortunately, very few cultural artefacts in Buryatia survived the Soviet era, the Buryats carried out the re-appropriation of the space with vigor in the post-Soviet period. The Tsugol temple began to play an important role as a symbol and object of the lost Buryat past.

In 1988, the datsan was returned to the Buddhist community with only three buildings preserved from the original ensemble of pre-revolutionary times. The transfer was reportedly gradual: "The servicemen settled on one side and the lamas here" (DS750616, Buryat man, 20 years old, Tsugol, 2012). For several years, the datsan remained empty, but it was open to the public for the first time and the local people were able to visit.

14 A fragment of the broadcast "Kurs na Vostok-2010" aired on June 28, 2010 by the TV Channel Zvezda, https://vk.com/videos-15846500?z=video15846500_148249551\%2Fclub15846500\%2Fpl_-15846500_-2, last accessed on January 20, 2019. 
In 1991, the local Buryat community appealed to the parliament of the Russian Federation and the Ministry of Culture for help with the restoration (see Figure 7). Eventually, donations from believers, and state and local administration funding helped with the restoration of the datsan. The best stonecutters, woodcarvers, blacksmiths, and carpenters arrived in Tsugol from different parts of the Aga district and Buryatia. A group of Buryat arts students from Ulan-Ude and their teachers practiced their skills on the restoration of the desecrated temples with the help of old photographs, drawings, and testimonies of the locals. A prominent Buryat artist, Dashi-Nima Dugarov, President of the All-Buryat Association of Cultural Development, was one of the leading figures in the restoration process. The matter of "authenticity", with regard to using every piece of every artefact, was very important. One lama recounted:

And it happened that the stupa [suburgan - A. Zh.] was demolished and a wall was built using the stupa material. There was a wall made of stones. And we, in turn, took this wall apart and put it back together as a suburgan, a stupa. (DS750616, Buryat man, 20 years old, Tsugol, 2012)

In 1990, the statue of Buddha Maidari was returned to Tsugol from the History of Religion Museum in what was then Leningrad, where it had been stored in pieces in a warehouse since the 1930s anti-religious campaign. This was a major symbolic event for the monastery and for the Buryat Buddhists. Not only were material objects returning, but also elements of non-material heritage. Some lamas who escaped to Inner Mongolia during the early Soviet period returned to contribute to the restoration and revive the "authentic" traditions practiced before the purges:

In Shenekhen [a place in Inner Mongolia, China] they built their own datsan and all the khurals [Buddhist religious service $-A$. Zh.] were held according to the Tsugol version ... Those lamas from Shenekhen revived the old ... brought from Inner Mongolia to us ... there, they preserved the way [the khurals $-A$. Zh.] were held in the old times and then, ... not themselves but their disciples, brought it back here ... all these old customs, they brought them here and taught them to us. (DS750613, Buryat man, 40 years old, Tsugol, 2012)

It is worth noting that in 1928 the Buryats who had escaped to Inner Mongolia built a copy of the Tsugol datsan on the right bank of the river Shenekhen (Hulun-Buir, China). During the Cultural Revolution in China, in 1966, the temple was destroyed, but was later restored in its original 
form in 1984 (for more on this, see Zhamsueva - Luvsan 2018). The Buryat lamas from Inner Mongolia who had lived as children in the monastic village of Tsugol would visit the place for sentimental reasons. Of course, few of them are still alive today, but it seems that in the 1980s and 1990s, after the loosening the border regime between China and Russia, many strove to see the place:

Our house was built by Russians, it is obvious [by its construction A. Zh.] that it was built by Russians. But not far from here, there is a house, my mother-in-law used to live in it, where lamas had lived. And he, a lama, in ... I don't remember exactly when, in the 1980s, he came back to see his house. Some of them [lamas] survived. He came to see the house ... some of them survived. (DS750616, Russian woman, 50 years old, Tsugol, 2012)

Only a few elderly lamas were seen in the monastery in 2012. Most disciples and lamas are relatively young Buryat men, but the numbers are still small. A local Russian woman said to me: "When I arrived here [in the 1970s], only one Buryat family lived here. ... There were no Buryats here. Now, there are some Buryats who have bought property, mainly near the temple. But before there was only one family" (DS750616, Russian woman, 50 years old, Tsugol, 2012).

The Tsugol settlement next to the monastery had 845 inhabitants as of 2017 and is still predominately Russian. The Buryats from the neighboring villages and other parts of the region visit Tsugol during major religious holidays, such as the lunar new year or summer Buddhist festivals. They long to visit one of the few surviving cultural heritage sites closed to them in the previous era, and the remnants of the military zone are not important for them. We were told that many local Russians now follow Buddhist practices in everyday life and visit the temple. It is reported that Buryat and Russian schoolchildren often visit the Buddhist stupas and perform goroo (the ritual walk around temple) before their exams or other important events in their lives. The datsan is now fully integrated into the everyday practices of the locals of whom the majority are Russians. This may be due to the fact that the area lacks a Russian Orthodox church or it may be a sign of a kind of syncretism, which is typical for Transbaikalia in general (Peshkov 2011), where the culture of local Russians has been influenced by the Buryat:

I walk around the temple and just think that maybe it will help. The spiritual sphere is single. I perceive all churches and temples as being like antennas that transmit information to the universe if used in the 
proper way. My sister also comes here. She carries a Christian cross - I ask her why? She answered ... there is one God. Maybe there is no need for a church here. If it is a holy place for Buryats, let's leave this way and not create any oppositions here ... Many Russians do visit the temple. (DS750616, Russian woman, 50 years old, Tsugol, 2012)

This is the way the "new" values and traditions are evolving together with the changing character of the place. As Demski and Czarnecka noted "In the process of constructing their own place, of 'bringing it out of' space, every group contributes to creating different configurations of 'things', incessantly gathered by place" (Demski - Czarnecka 2015: 114-115). The locals, Russians and Buryats, see the temple as a major landmark. While the place remains on the geographical periphery in comparison with other Buryat religious and cultural centers, Tsugol datsan, as a monastery, is now fully re-appropriated in actual and symbolic ways.

\section{Conclusion}

A keen observer of post-Soviet Buryat culture would notice that the Buryats' imagination of their own "traditional" culture is generally presented free of the signs of Soviet modernity. Perhaps that is why, when visiting Tsugol for the first time, I was not expecting to see the datsan in urbanized, though dilapidated, surroundings. Nowadays, the Tsugol monastery exists for Buryats as a de-territorialized symbol linking them with their own pre-Soviet past. The Soviet military zone period is now marginalized in local memory and ignored in the Buryat discourse. Re-appropriation of the cultural landscape in this sense is not merely a procedure of returning the objects to their original places or previous "masters", it is the process of reconsidering history and the past in general.

The Tsugol military zone (1933-1988) was created in a place with its own history, a place of high cultural importance for the Buryat people. During the military zone period, there was an attempt to clean the place of its previous cultural meanings by expelling the Buryat population, isolating the place, and destroying the Buddhist and Buryat identity through symbolic alienation and appropriation. Since 1988, the place has been re-appropriated by the Buryats as a major religious and cultural center although now far removed from contemporary Buryat centers. The Buryats believe that the place possesses its own subjectivity and agency, which helped it to survive the Soviet period. At the same time, the more recent non-Buryat population of the area also claims to have contributed to preserving the place and accept it as sacred. They also have their own story of their at- 
tachment to the place during the military zone period and currently when it is a monastery once again. These developments provide reasons for considering this place a processual and multilocal phenomenon, experienced differently by different communities. As time passes, new stories, meanings and emotions are being attached to the place, creating more layers of the cultural landscape.

fuly 2020

\section{Bibliography}

Andreev I. 1997. 'Poverzhennye datsany.' In: Sinitsyn, Fyodor L. 2013. Krasnaya burya: Sovetskoe gosudarstvo i buddizm v 1917-1946g. SaintPetersburg: Izdatel'stvo A. A. Terentyev: 441-481.

Boronoeva, Darima. 2006. Vozniknovienie buriatskoi diaspory za rubiezhom. Diaspory v kontiekstie sovremiennych etnokulturnykh $i$ etnosotsialnych processov, volume 3: 33-47.

Casey, Edward S. 1996. 'How to get from space to place in a fairly short stretch of time. Phenomenological prolegomena'. In: Steven, F. - Keith, H. B. (eds): Senses of Place. Santa Fe: School of American Research Press: $13-47$.

Clifford, James. 2000. Kłopoty z kultura. Dwudziestowieczna etnografia, literatura i sztuka. Transl. Ewa Dżurak, Joanna Iracka, Ewa Klekot, Maciej Krupa, Sławomir Sikora, Monika Sznajderman. Warsaw: Wyd. KRa.

Demski, Dagnosław - Czarnecka, Dominika. 2015. 'Mapping Meanings in the Post-Soviet Landscape of Borne Sulinowo'. Latvijas Vēstures institūta Žurnāls 2, 95: 96-120.

Dondukov, Bato. 2019. The Struggle for "Trueness" of Buddhism: Internet as a Space of Dialogues and Conflicts in Buddhist Communities of Russia. $\mathrm{PhD}$ dissertation written under the supervision of prof. dr. hab. Ewa Łukaszyk. Warsaw.

Gerson, Michael S. 2010. The Sino-Soviet Border Conflict: Deterrence, Escalation, and the Threat of Nuclear War in 1969. Center for Naval Analyses. [2019-03-30] Retrieved from: https://www.cna.org/cna_files/ pdf/d0022974.a2.pdf.

Humphrey, Caroline. 2014. Discussion of the project "Where Rising Powers Meet: China and Russia At Their North Asian Border" [2020-25-08] Retrieved from: https://www.youtube.com/ watch?v=nwawKQGS03o\&t=9s. 
Humphrey, Caroline. 2015. 'Remote' areas and minoritized spatial orders at the Russia - Mongolia border. Études mongoles et sibériennes, centrasiatiques et tibétaines, 46 [2020-25-08] Retrieved from: http://journals.openedition.org/emscat/2542

Kradin, Nikolay - Baksheeva, Svetlana - Prokopets, Stanislav. 2018. 'Cities and palaces of the Mongol Empire in Eastern Transbaikalia'. Sibirskie istoricheskie issledovania 2: 65-80.

Latour, Bruno. 1993. We Have Never Been Modern. London: Harvester Wheatsheaf.

Namsaraeva, Sayana. 2012. 'Ritual, Memory and the Buriad Diaspora Notion of Home'. Frontier Encounters: Knowledge and Practice at the Russian, Chinese and Mongolian Border. [2019-03-30] Retrieved from: http://books.openedition.org/obp/1537.

Nimaev, Daba. 1993. Naselenie Buryatii i formirovanie ego natsional'nogo sostava. Respublike Buryatii 70 let: 41-49.

Peshkov, Ivan. 2011. 'Pamyat' v kulturesoobshchestv starozhilov vo Vnutrenney Mongolii'. Debaty Artes Liberales: Tsivilizatsionny yybor i pogranichie, vol. IV: 109-128.

Peshkov, Ivan. 2014. 'Usable Past for a Transbaikalian Borderline Town 'Disarmament' of Memory and Geographical Imagination in Priargunsk'. Inner Asia 16: 95-115.

Rodman, Margaret C. 1992. 'Empowering Place: Multilocality and Multivocality'. American Anthropologist, New Series, 94, 3: 640-656.

Seljamaa, Elo-Hanna - Czarnecka, Dominika - Demski, Dagnosław. 2017. 'Small Places, Large Issues: Between Military Space and PostMilitary Place'. Folklore. Electronic Fournal of Folklore 70: 7-18.

Sinitsyn, Fyodor L. 2013. Krasnaya burya: Sovetskoe gosudarstvo i buddizm v 1917-1946 g. Saint-Petersburg: Izdatel'stvo A. A. Terentyev.

Smyrski, Łukasz. 2018. Między roładza spojrzenia a praktyka. Antropologia krajobrazu. Warsaw: Oficyna Naukowa.

Szacka, Barbara. 2006. Czas przeszty, pamięć, mity. Warsaw: Wydawnictwo Naukowe SCHOLAR.

Szmyt, Zbigniew. 2013. "Modern Nomads." Antropologicheskie ocherki sovremennykh buriackikh migratsyi v Rossii. Irkutsk: Ottisk.

Tsyrendashiev, Dambinima. 2008. Süügelei dasan: domog, tüükhe, barimtanuud (XIX-dekhi zuun zhel). Ulan-Ude: Respublikanskaya tipografia.

Vanchikova, Tsymzhit - Gomboeva, Margarita. 2010. Filosofskie shkoly buddijskih monastyrej Vostochnogo Zabajkal'ya kak istorikokul'turnaya predposylka epohi buryatskogo Prosveshcheniya. Gumanitarnyj vektor. Seriya: Pedagogika, psihologiya 4, 24: 44-49. 
Wierzejska, Jagoda - Shumylovych, Bohdan. 2018. Tworzenie

i przetwarzanie krajobrazu: o symbolicznym przywłaszczaniu Karpat. [2020-25-08] Public lecture available at: https://www.youtube.com/ watch?v=lCNoet-uNoA.

Wierzejska, Jagoda - Shumylovych, Bohdan. Symbolic Appropriation. Lecture on Ideologization of the Carpathians in the Interwar Poland and in Soviet Ukraine. [2020-01-30] https://www.lvivcenter.org/en/ chronicle/news/2665-18-02-01-symbolic-appropriation/ (the page is not available).

Zhamsueva, Darima - Luvsan, Oyuuntsetseg. 2018. Tsugol'skij

i Shenekhenskij dacany v sravnitel'nom aspekte. Vlast' 9: 212-216.

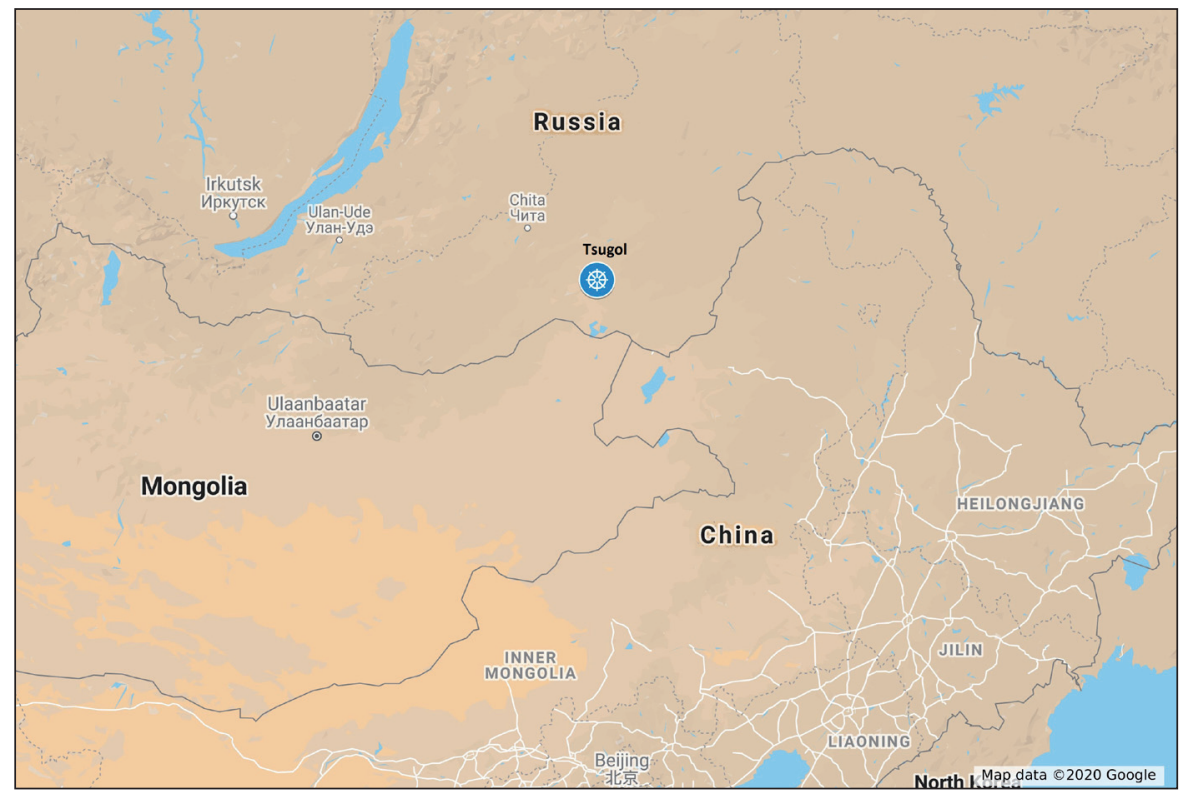

Figure 1 Map of Transbaikalia with location of Tsugol (source: google map service, 2020) 


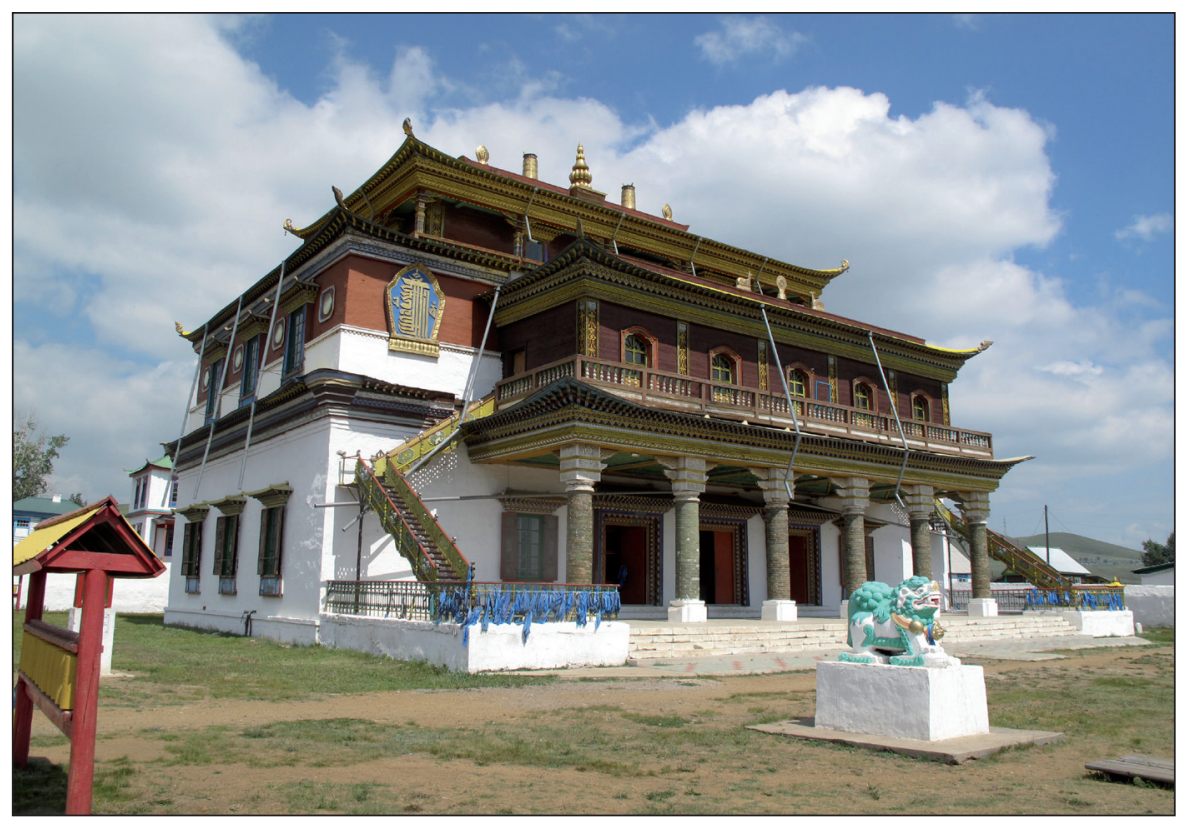

Figure 2 The main temple of Tsugol datsan (source: Ayur Zhanaev, 2012)

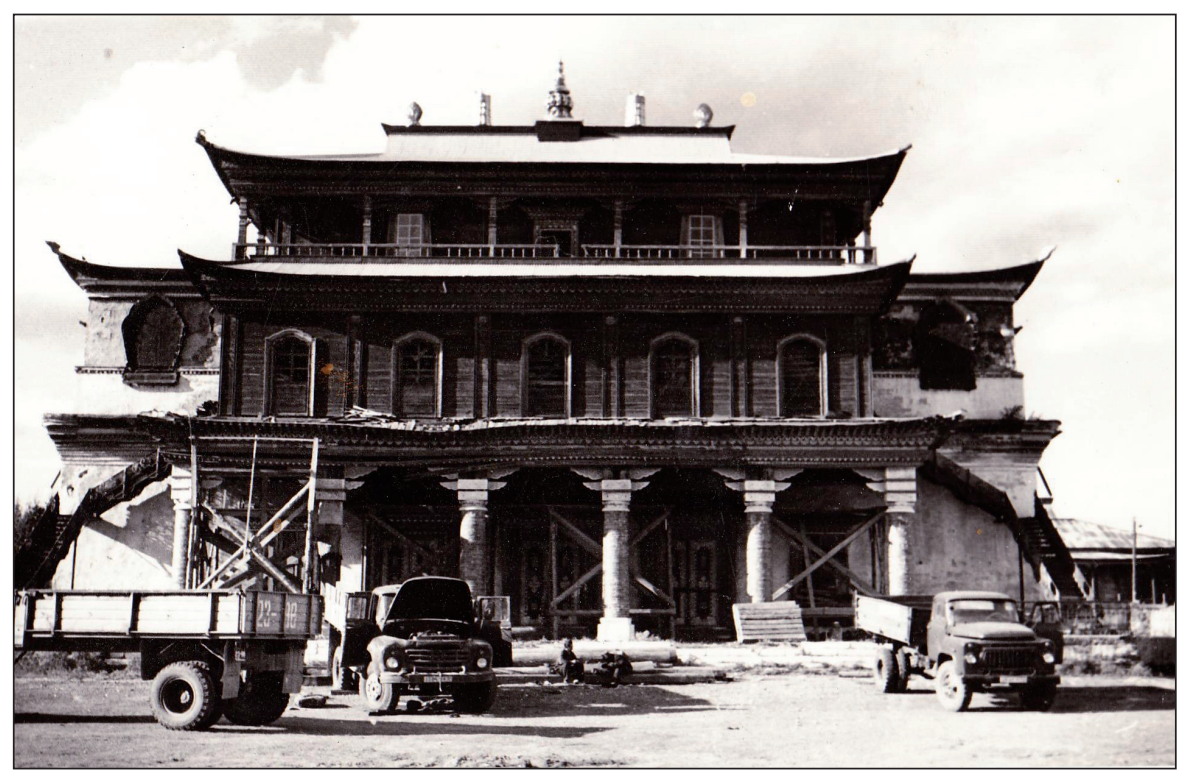

Figure 3 Tsugol datsan as a military zone during Soviet times (source: Open data of the Ministry of Culture of the Russian Federation, ASM-OF 1557/28, https://opendata.mkrf.ru/) 


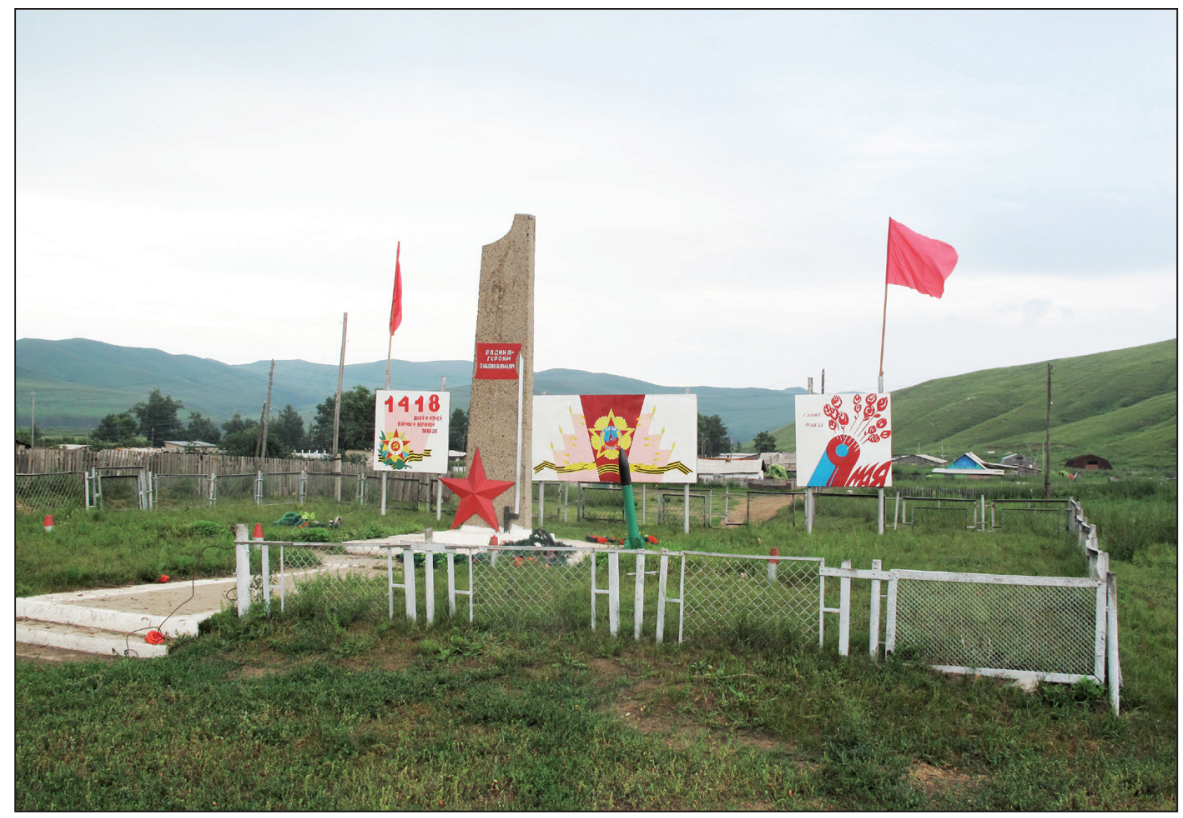

Figure 4 Monument commemorating victory in WWII, the so-called "Pamyatnik" (source: Ayur Zhanaev, 2012)

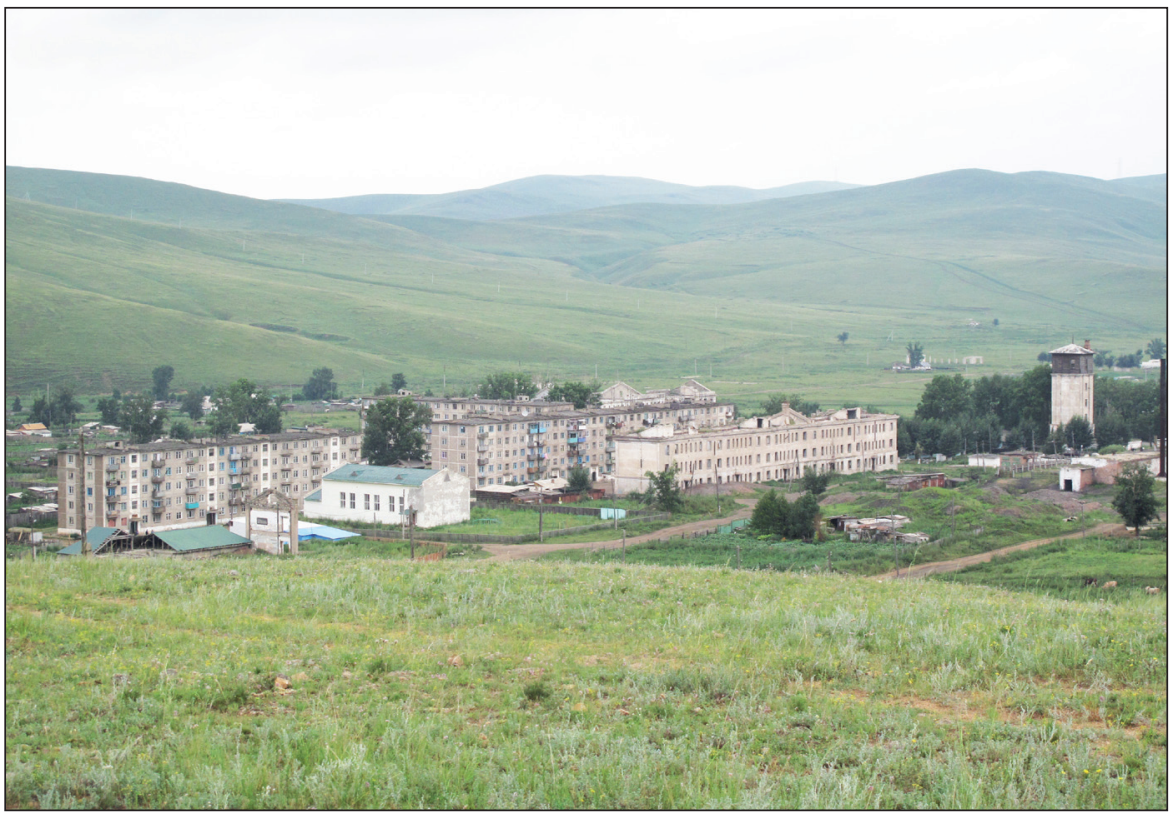

Figure 5 North-eastern part of Tsugol (source: Ayur Zhanaev, 2012) 


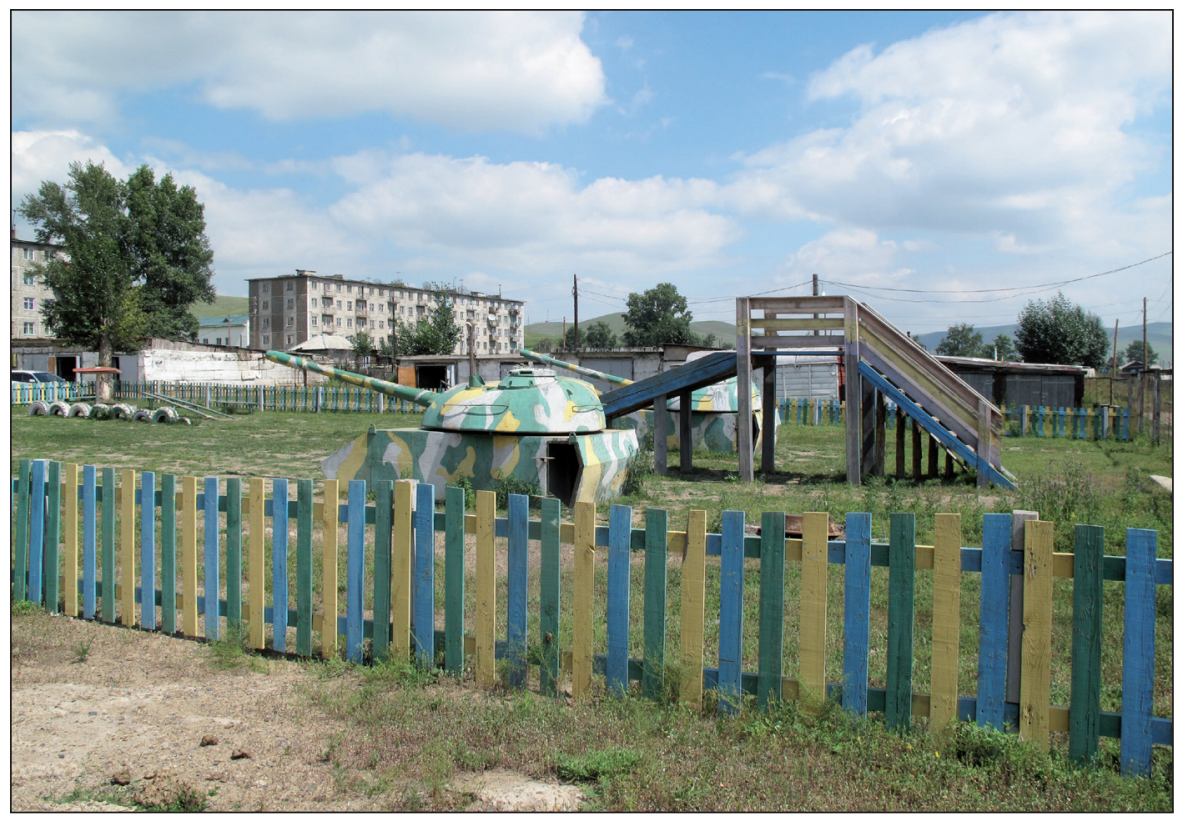

Figure 6 A playground organized as a battlefield with tanks (source: Ayur Zhanaev, 2012)

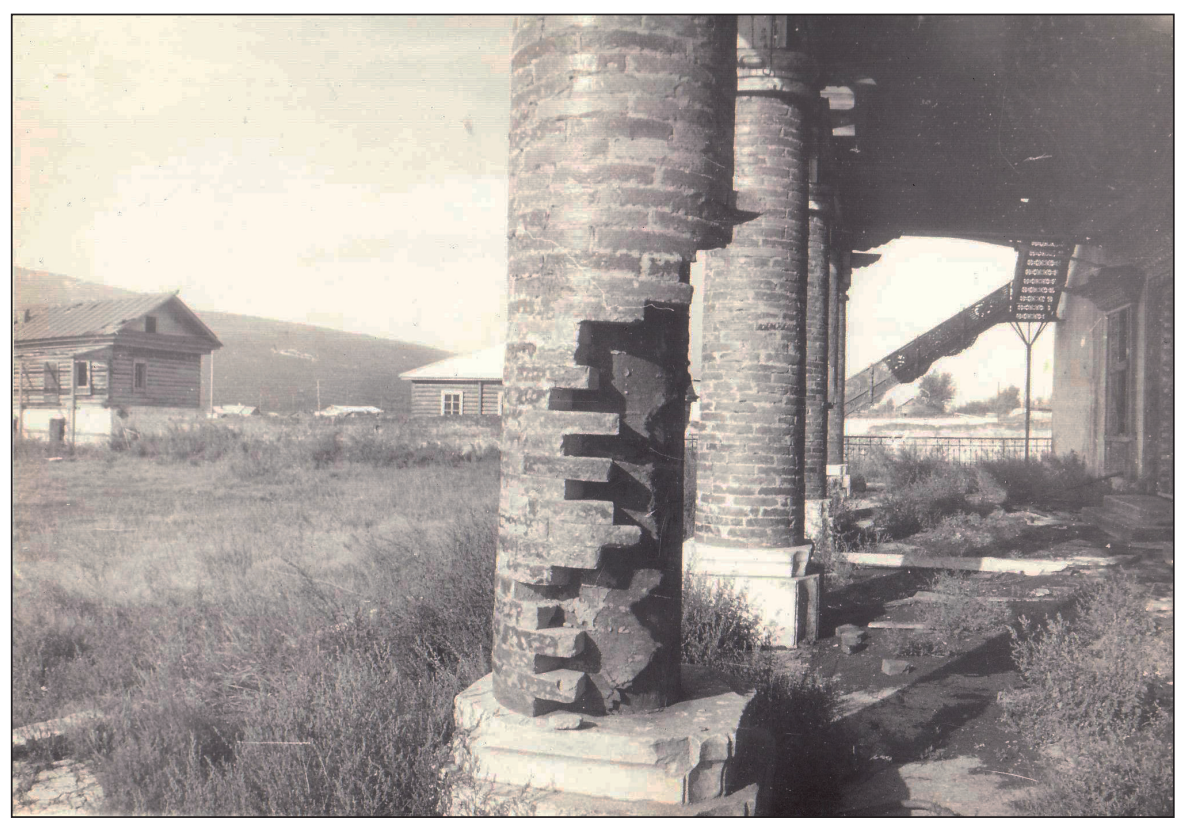

Figure 7 Columns of the main shrine (source: Open data of the Ministry of Culture of the Russian Federation, ASM-OF 1557/31, https://opendata.mkrf.ru/) 